\title{
Study on knowledge of medicinal plants used of Tay ethnic minority in Na Hang special-use forest, Tuyen Quang Province
}

\author{
Nghiên cứu tri thức sủ dụng cây thuốc của đồng bào người Tày tại khu bảo tồn \\ rùng đặc dụng Na Hang, tỉnh Tuyên Quang
}

Research article

Nguyen Thi Hai ${ }^{1,2}$, Chu Thi Thu Ha ${ }^{2}$, Nguyen The Cuong ${ }^{2}$, Nguyen Anh Tuan ${ }^{3}$, Tran Huy $\mathrm{Thai}^{2} *$

${ }^{1}$ Tan Trao University, Tuyen Quang, Vietnam; ${ }^{2}$ Institute of Ecology and Biological Resources, Vietnam Academy of Science and Technology, 18 Hoang Quoc Viet, Cau Giay, Hanoi, Vietnam; ${ }^{3}$ Publishing House for Science and Technology, Vietnam Academy of Science and Technology, 18 Hoang Quoc Viet, Cau Giay, Hanoi, Vietnam

\begin{abstract}
Tay ethnic minority using Tay - Thai language is the biggest population in Na Hang district (ca. $51.6 \%)$, Tuyen Quang province. Their knowledge and experience of using medicinal plants have been preserved and passed down through many generations. Medicinal plant resources in Na Hang special-use forests (SUF) have been contributing to the work of health care and treatment of communities in the region. Research results showed that the composition of medicinal plants used by Tay ethnic minority in Na Hang SUF included 223 vascular plant species, belonging to 4 phyla which were mainly belonging to Magnoliophyta, accounting for $90.0 \%$ of families; $94.97 \%$ of genera, and $95.92 \%$ of species. Among these 223 plant species, 9 species were ranked at different levels of endangered status. These are rare and precious gene sources that need to be strictly protected and conserved. 53 diseases/symptoms belonging to 7 groups of diseases can be treated with medicinal plants from Tay ethnic minority in Na Hang SUF. Particularly, 14 diseases to be treated by various medicinal herbs.
\end{abstract}

Dân tộc Tày là một cộng đồng thuộc ngôn ngũu Tày - Thái và có dân số đông nhất ở huyện Na Hang, tỉnh Tuyên Quang, chiếm 51,6\% tổng dân số toàn huyện. Nhũng tri thức và kinh nghiệm sư dụng nhũng loài cây để chũa bệnh đã được người dân địa phưong gìn giũu và luu truyền lại qua nhiều đời, thế hệ sau. Nguồn tài nguyên cây thuốc ở rùng đặc dụng Na Hang đã và đang đóng góp vào công tác chăm sóc súc khoẻ và chũa bệnh của các cộng đồng trong khu vục. Kết quả điều tra cho thấy thành phần loài cây thuốc được người dân tộc Tày sử dụng gồm 223 loài thuộc 4 ngành thực vật bậc cao có mạch, chủ yếu thuộc ngành Mộc Lan (Magnoliophyta), chiếm 90,0\% tổng số họ; 94,97\% tổng số chi và 95,52\% tổng số loài. Trong số 223 loài cây thuốc này, có 9 loài được xếp ở các cấp độ nguy cấp khác nhau. Đây là nguồn gien quý hiếm, cần có biện pháp bảo tồn nghiêm ngặt. Có 53 bệnh/triệu chứng bệnh thuộc 7 nhóm bệnh có thể chũa bằng cây thuốc tại rùng đặc dụng Na Hang tù người dân tộc Tày. Đặc biệt, 14 bệnh có thể chũa được bằng nhiều loại cây thuốc khác nhau.

Keywords: medicinal plants, Na Hang special-use forest, Tay ethnic minority

\section{Introduction}

$\mathrm{Na}$ Hang special-use forest (SUF), formerly Tat Ke - Ban Bung Nature reserve, was found by the decision of The Tuyen Quang province People's Committee on May 9th, 1994 (Decision 274/QĐ-UB). It locates on the area of Khau Tinh, Con Lon, Son Phu, Thanh Tuong communes, Na
Hang district, Tuyen Quang province. Na Hang SUF covers approximately $22,401.5$ hectares, in which elevation less than $300 \mathrm{~m}$ alt. covers ca. 30\% area, elevation less from 300 to $800 \mathrm{~m}$ alt. covers ca. $60 \%$, and above $900 \mathrm{~m}$ alt. covers ca. $10 \%$. The average temperature in winter is from $15^{\circ} \mathrm{C}$ to $20^{\circ} \mathrm{C}$, and in summer is $30^{\circ} \mathrm{C}$. There are two major rivers flowing through this area, Gam river (west of 
Tat $\mathrm{Ke}$ ) and Nang river (east Na Hang). Currently, water from Na Hang SUF is distributed, conditioned by the reservoir system and $\mathrm{Na}$ Hang dam.

The flora of Na Hang SUF comprised 1162 vascular plant species, belonging to 604 genera, 159 families, 4 phyla. In which Angiospermae comprised 1083 species, 570 genera, 135 families; Gymnospermae comprised 11 species, 8 genera, 5 families; Polypodiophyta comprised 63 species, 34 genera, 17 families; and Lycopodiophyta comprised 5 species, 2 genera, 2 families. 558 vascular plant species in $\mathrm{Na}$ Hang SUF were recognized as medicinal plants [14].

However, so far there have been no studies on the distribution characteristics, capacity for regeneration of medicinal plants, especially promising species in $\mathrm{Na}$ Hang SUF. Study on knowledge of medicinal plants used of Tay ethnic minority in Na Hang SUF in order to initially assess the distribution characteristics and regeneration capacity of promising medicinal plants in that area.

Tay ethnic minority uses Tay - Thai language and it is the biggest population in $\mathrm{Na}$ Hang district (ca. 51.6\%). In $\mathrm{Na}$
Hang, Tay ethnic minority lives in intermingled area with other ethnic groups along streams concentrated in Thanh Tuong, Phu Son, Khau Tinh communes. The herb doctors in Tay ethnic minority collect and use varieties of medicinal plants. The knowledge and experience of using the medicinal plants have been preserved and passed down through many generations. Nowadays, Tay ethnic people, especially herb doctors, have planted many kinds of medicinal plants in their garden while medicinal plants resources gradually scarce. However, with certain amount of medicinal plants planted in the garden, and many medicinal plant species could not be planted, Tay ethnic people still collect and use the medicinal plant resources from natural forest.

\section{Materials and methods}

\subsection{Study sites}

Studies were carried out in Thanh Tuong, Son Phu, Khau Tinh communes, Na Hang district, Tuyen Quang province (table 1).

Table 1. Time and study sites

\begin{tabular}{cl} 
No. Study sites \\
\hline 1 & \multicolumn{1}{c}{\begin{tabular}{l}
\multicolumn{1}{c}{ Khuoi Boc village, Thanh Tuong commune, } \\
Na Hang district
\end{tabular}} \\
2 & $\begin{array}{l}\text { Bung village, Thanh Tuong commune, Na } \\
\text { Hang district }\end{array}$ \\
3 & $\begin{array}{l}\text { Chu village, Son Phu commune, Na Hang dis- } \\
\text { trict }\end{array}$ \\
4 & $\begin{array}{l}\text { Thac Mo village, Son Phu commune, Na Hang } \\
\text { district } \\
\text { Nà Tang village, Khau Tinh commune, Na }\end{array}$ \\
5 & $\begin{array}{l}\text { Hang district } \\
\end{array}$
\end{tabular}

\subsection{Materials}

The medicinal plants were investigated and collected in the study sites and were kept in The Herbarium, Institute of Ecology and Biological Resources, Vietnam Academy of Science and Technology, Hanoi, Vietnam.

\subsection{Methods}

Using participant observation and semi-structured interview, data on the local knowledge in collecting and using medicinal plants by Tay ethnic people in Na Hang SUF.

Key informants were identified on the basis of semi-structured interviews for transect walks through the surrounding mountains and fields to collect the documented plants for samples and voucher specimens. Picture cards with medicinal plants were shown to informants to document local knowledge. The process of identifying the names and descriptions of plants is based on morphological characters.

\begin{tabular}{|c|c|c|}
\hline Time & Co-ordinates & Altitude \\
\hline May, 23th-24 ${ }^{\text {th }}, 2014$ & $\begin{array}{l}\text { N: } 22.17^{\prime} 33,4^{\prime \prime} ; \\
\text { E: } 105.24 ' 38,1^{\prime \prime}\end{array}$ & $120 \mathrm{~m}$ \\
\hline May, 20th-22th, 2014 & $\mathrm{~N}: 22.15^{\prime} 44,2^{\prime \prime}$ & \\
\hline $\begin{array}{l}\text { October, 10th-12th, } 2014 \\
\text { April, 10th-15th, } 2015\end{array}$ & E: $105.25^{\prime} 48,5^{\prime \prime}$ & $349 \mathrm{~m}-432 \mathrm{~m}$ \\
\hline October, 13th-15th, 2014 & $\begin{array}{l}\mathrm{N}: 22.20^{\prime} 54,1^{\prime \prime} ; \\
\mathrm{E}: 105.25^{\prime} 45,5^{\prime \prime}\end{array}$ & $259 \mathrm{~m}$ \\
\hline $\begin{array}{c}\text { May, 25th-26th, } 2014 \\
\text { October, 16th-18th, } 2014\end{array}$ & $\begin{array}{l}\mathrm{N}: 22.21^{\prime} 08,2^{\prime \prime} ; \\
\mathrm{E}: 105.25^{\prime} 11,7^{\prime \prime}\end{array}$ & $194 \mathrm{~m}-418 \mathrm{~m}$ \\
\hline October, 19th-22th, 2014 & $\begin{array}{l}\text { N: } 22.27 ' 52,2^{\prime \prime} \\
\text { E: } 105.26^{\prime} 19,4 "\end{array}$ & $774 \mathrm{~m}-891 \mathrm{~m}$ \\
\hline
\end{tabular}

\section{Results and discussion}

\subsection{Medicinal plants diversity in Na Hang SUF, Tuyen Quang province}

Based on the results of our studies on medicinal plants in $\mathrm{Na}$ Hang SUF and considering carefully previous studies, we have recorded 275 medicinal plant species, belonging to 204 genera, 96 families of vascular plants which have been used by local people in that area (Table 2).

Table 2 showed that, the composition of medicinal plants in Na Hang SUF was mainly belonging to Magnoliophyta, accounting for $90.63 \%$ of families; $95.59 \%$ of genera, and $96.00 \%$ of species. In other phyla, the number of families, genera and medicinal plant species were smaller. In Magnoliophyta, Magnoliopsida comprised $73.96 \%$ of families, $78.43 \%$ of genera and $80.00 \%$ of species; and Liliopsida comprised $16.67 \%$ of families, $17.16 \%$ of genera, $16.00 \%$ of species. 
Table 2. Composition of medicinal plants in Na Hang SUF

\begin{tabular}{clcccccc} 
& & \multicolumn{2}{c}{ Families } & \multicolumn{2}{c}{ Genera } & \multicolumn{2}{c}{ Species } \\
\cline { 3 - 8 } No. & Phyla & $\begin{array}{c}\text { Number of } \\
\text { speices }\end{array}$ & Percentage & $\begin{array}{c}\text { Number } \\
\text { of genera }\end{array}$ & Percentage & $\begin{array}{c}\text { Number of } \\
\text { species }\end{array}$ & Percentage \\
\hline 1 & Lycopodiophyta & 1 & 1,04 & 1 & 0,49 & 2 & 0.73 \\
2 & Polypodiophyta & 7 & 7,29 & 7 & 3,43 & 8 & 2.91 \\
3 & Pinophyta & 1 & 1,04 & 1 & 0,49 & 1 & 0.36 \\
4 & Magnoliophyta & 87 & 90,63 & 195 & 95,59 & 264 & 96.00
\end{tabular}

There were 10 families, which comprised numerous medicinal plant species as: Rubiaceae (20 species), Urticaceae (19 species), Acanthaceae (9 species), Euphorbiaceae (9 species), Araceae, (9 species), Zingiberaceae (9 species), Verbenaceae ( 8 species), Moraceae (7 species), Asteraceae (7 species), Convallariaceae ( 7 species). And there were 4 genera, which comprised numerous medicinal plant species as: Ficus (6 species), Piper ( 5 species), Elastostema (5 species), Clerodendrum (5 species).

\subsection{Composition of medicinal plants used by Tay ethnic minority in Na Hang SUF}

Table 3 shows that, the composition of medicinal plants used by Tay ethnic minority in Na Hang SUF included 223 vascular plant species, belonging to 4 phyla which were mainly belonging to Magnoliophyta, accounting for $90.0 \%$ of families; $94.97 \%$ of genera, and $95.92 \%$ of species. In other phyla, the number of families, genera and medicinal plant species were smaller. In Magnoliophyta, Magnoliopsida comprised $72.22 \%$ of families, $77.09 \%$ of genera and $78.03 \%$ of species; and Liliopsida comprised $17.78 \%$ of families, $17.88 \%$ of genera, $17.49 \%$ of species.

There were 12 families, which comprised numerous medicinal plant species used by Tay ethnic minority as: Rubiaceae (18 species), Urticaceae (15 species), Acanthaceae (9 species), Euphorbiaceae (9 species), Zingberaceae (9 species), Asteraceae (7 species), Araceae (7 species), Piperaceae (6 species), Menispermaceae ( 5 species), Myrsinaceae ( 5 species), Rutaceae ( 5 species), Vitaceae ( 5 species). And there were 3 genera, which comprised numerous medicinal plant species used by Tay ethnic minority as: Piper (5 species), Elastostema (5 species), Psychotria (4 species).

The comparison between the number of medicinal plant species used by Tay ethnic minority with total medicinal plant species in Na Hang SUF was shown in table 4.

Table 3. Composition of medicinal plants used by Tay ethnic minority in Na Hang SUF

\begin{tabular}{clcccccc} 
& & \multicolumn{2}{c}{ Families } & \multicolumn{2}{c}{ Genera } & \multicolumn{2}{c}{ Species } \\
\cline { 3 - 7 } No. & Phyla & $\begin{array}{c}\text { Number of } \\
\text { speices }\end{array}$ & Percentage & $\begin{array}{c}\text { Number of } \\
\text { genera }\end{array}$ & Percentage & $\begin{array}{c}\text { Number of } \\
\text { species }\end{array}$ & Percentage \\
\hline 1 & Lycopodiophyta & 1 & 1,10 & 1 & 0,56 & 2 & 0.90 \\
2 & Polypodiophyta & 7 & 7,78 & 7 & 3,91 & 7 & 3.14 \\
3 & Pinophyta & 1 & 1,11 & 1 & 0,56 & 1 & 0.45 \\
4 & Magnoliophyta & 81 & 90,0 & 170 & 94,97 & 213 & 95.52 \\
& Total & $\mathbf{9 0}$ & & $\mathbf{1 7 9}$ & & $\mathbf{2 2 3}$ &
\end{tabular}

Table 4. Proportion of medicinal plant species used by Tay ethnic minority

\begin{tabular}{rlccc} 
No. & Phyla & Total species in & \multicolumn{2}{c}{ Total species used by Tay ethnic people } \\
\cline { 4 - 5 } & & Na Hang & Number of species & Percentage \\
\hline 1 & Lycopodiophyta & 2 & 2 & 0.73 \\
2 & Polypodiophyta & 7 & 7 & 2.55 \\
3 & Pinophyta & 1 & 1 & 0.36 \\
4 & Magnoliophyta & 265 & 213 & 77.45 \\
& Total & $\mathbf{2 7 5}$ & $\mathbf{2 2 3}$ & $\mathbf{8 1 . 0 9}$
\end{tabular}

\subsection{Endangered medicinal plant species}

There were 7 endangered medicinal plant species in $\mathrm{Na}$ Hang SUF listed in Vietnam Red Data Book (2007) - Part II: Plants. In which, 4 species were ranked at Endangered (EN) level, and 3 species were ranked at Vulnerable (VU) level. 9 endangered medicinal plant species in $\mathrm{Na}$ Hang
SUF were listed in The Red List of Medicinal Plants of Vietnam (2006): 1 species was ranked at Critically Endangered level (CR), 4 species were ranked at Endangered (EN) level, and 4 species were ranked in Vulnerable (VU) level. 2 endangered medicinal plant species in $\mathrm{Na}$ Hang SUF were listed in Degree 32/2006/NĐ-CP (Appendix II, those are species that are not necessarily threatened with extinction, but limited exploitation or use for commercial purposes) (Table 5). 
Table 5. Endangered medicinal plant species in Na Hang SUF

\begin{tabular}{|c|c|c|c|c|c|}
\hline No. & Latin name & $\begin{array}{l}\text { Vietnamese/Tay } \\
\text { names }\end{array}$ & $\begin{array}{l}\text { Vietnam } \\
\text { Red Data } \\
\text { Book (2007) }\end{array}$ & $\begin{array}{l}\text { Degree } \\
\text { 32/2006/NĐ- } \\
\text { CP }(2006)\end{array}$ & $\begin{array}{l}\text { The Red List } \\
\text { of Medicinal } \\
\text { Plants of Vi- } \\
\text { etnam (2006) }\end{array}$ \\
\hline 1 & $\begin{array}{l}\text { Asarum balansae Franch. } \\
\text { (Aristolochiaceae)** }\end{array}$ & $\begin{array}{l}\text { Té tân balansa/Muầu } \\
\text { đin }\end{array}$ & $\begin{array}{l}\text { EN A1c,d, } \\
\text { B } 1+2 b, c\end{array}$ & IIA & $\begin{array}{c}\text { CR } \\
\text { A } 1 \mathrm{c}, \mathrm{d} . \\
\mathrm{B} 1+2 \mathrm{~b}, \mathrm{c}\end{array}$ \\
\hline 2 & $\begin{array}{l}\text { Asarum caudigerum Hance } \\
\text { (Aristolochiaceae) }\end{array}$ & Tế tân & VU A1c,d & IIA & $\begin{array}{c}\mathrm{VU} \\
\mathrm{A} 1 \mathrm{a}, \mathrm{c}, \mathrm{d}\end{array}$ \\
\hline 3 & $\begin{array}{l}\text { Balanophora laxiflora Hesml. } \\
\text { (Balanophoraceae) }\end{array}$ & $\begin{array}{l}\text { Dương đài (Tỏa } \\
\text { dương)/Pi đin }\end{array}$ & $\begin{array}{c}\mathrm{EN} \\
\mathrm{B} 1+2 \mathrm{~b}, \mathrm{c}, \mathrm{e}\end{array}$ & & $\begin{array}{l}\text { VU } \\
\text { A1c,d }\end{array}$ \\
\hline 4 & $\begin{array}{l}\text { Podophyllum tonkinensis Gagnep. } \\
\text { (Berberidaceae) }\end{array}$ & $\begin{array}{l}\text { Bát giác liên/Bâu chất } \\
\text { cooc }\end{array}$ & EN Ala,c,d & & $\begin{array}{c}\mathrm{EN} \\
\mathrm{A} 1 \mathrm{c}, \mathrm{d}\end{array}$ \\
\hline 5 & $\begin{array}{l}\text { Gynostemma pentaphyllum } \\
\text { (Thunb.) Makino } \\
\text { (Cucurbitaceae) }\end{array}$ & $\begin{array}{l}\text { Giảo cổ lam/Pyắc dạ; } \\
\text { Lày im }\end{array}$ & EN A1a,c,d & & $\begin{array}{c}\mathrm{EN} \\
\mathrm{A} 1 \mathrm{a}, \mathrm{c}, \mathrm{d}\end{array}$ \\
\hline 6 & $\begin{array}{l}\text { Ardisia silvestris Pitard } \\
\text { (Myrsinaceae) }\end{array}$ & Lá khôi & $\begin{array}{c}\mathrm{VU} \\
\mathrm{A} 1 \mathrm{a}, \mathrm{c}, \mathrm{d}+2 \mathrm{~d}\end{array}$ & & $\begin{array}{l}\text { VU } \\
\text { A1c,d }\end{array}$ \\
\hline 7 & $\begin{array}{l}\text { Kadsura coccinea (Lem.) A.C. } \\
\text { Smith } \\
\text { (Schisandeaceae) }\end{array}$ & $\begin{array}{l}\mathrm{Na} \text { rừng/Thau nồm } \\
\text { noa }\end{array}$ & & & $\begin{array}{c}\mathrm{EN} \\
\mathrm{A} 1 \mathrm{c}, \mathrm{d}\end{array}$ \\
\hline 8 & $\begin{array}{l}\text { Disporopsis longifolia Craib } \\
\text { (Liliaceae) }\end{array}$ & $\begin{array}{l}\text { Hoàng tinh cách } / \mathrm{Ca} \\
\text { lài }\end{array}$ & & & $\begin{array}{c}\text { EN } \\
\text { Ala,c,d }\end{array}$ \\
\hline 9 & $\begin{array}{l}\text { Drynaria bonii Christ. } \\
\text { (Polypodiaceae) }\end{array}$ & $\begin{array}{l}\text { Tắc kè đá/Rằng ca } \\
\text { véng }\end{array}$ & $\begin{array}{l}\text { VU } \\
\text { A1c,d }\end{array}$ & & $\begin{array}{c}\text { VU } \\
\text { Ala,c,d }\end{array}$ \\
\hline
\end{tabular}

Note: in the brackets are family names of plant

\subsection{Diversity in life-form of medicinal plants used by Tay ethnic minority in Na Hang SUF}

Table 6. Life-form of medicinal plants used by Tay ethnic minority in Na Hang SUF

\begin{tabular}{llcc} 
No & Life-form & Number of speices & Percentage \\
\hline 1 & Trees & 36 & 16.14 \\
2 & Shrub & 48 & 21.52 \\
3 & Climber & 33 & 14.80 \\
4 & Herbs & 102 & 45.74 \\
5 & Epiphyte & 3 & 1.35 \\
6 & Parasite & 1 & 0.45 \\
& Total & $\mathbf{2 2 3}$ &
\end{tabular}

The vascular plants in Na Hang SUF, Tuyen Quang province had diverse life-forms. And most of medicinal plants used by Tay ethnic minority in Na Hang SUF were herbs, with 102 species (accounting for $45.74 \%$ of the total number of species) and shrub (accounting for $21.52 \%$ ); trees and climber were used fewer $(16.14 \%$ and $14.80 \%$, respectively); epiphyte and parasite account for a very low percent. This accurately reflected on usage of medicinal plants of the peoples in Vietnam, in general herbs and shrub are still life-forms which are used as medicines most (Table 6).

\subsection{Parts used for medicines}

There are 9 plant parts listed in method of using medicinal plants of Tay ethnic minority in Na Hang Special-use Forest, Tuyen Quang province (Table 7). Where, the most commonly used parts were Stem (accounting for 29,69\%), Leaves $(25,0 \%)$ and Root $(17,58 \%)$; number of species which had all parts used for medicines accounted for $18,36 \%$, other parts such as tuber, seed, plant hairs, stem bark and root bark were used less commonly.

Table 7. Plant parts used as medicines of Tay ethnic minority

\begin{tabular}{clcc} 
No. & Part used & Number of species & Percentage \\
\hline 1 & Whole plant & 47 & 18.36 \\
2 & Stem & 76 & 29.69 \\
3 & Leaves & 64 & 25.0 \\
4 & Root & 45 & 17.58 \\
5 & Tuber & 9 & 3.52 \\
6 & Fruit & 5 & 1.95 \\
7 & Seed & 5 & 1.95 \\
8 & Plant hairs & 1 & 0.39 \\
9 & Stem bark & 4 & 1.56 \\
& Total & $\mathbf{2 5 6}$ &
\end{tabular}

\subsection{Usage of medicinal plants}

Usage of medicinal plants of Tay ethnic minority in $\mathrm{Na}$ Hang Special-use Forest was quite diverse. Among 9 usages identified (Table 8), where, oral administration was major (148 species, accounting for $66.37 \%)$, dressing (41 species, 18.39\%) and bath, shampoo (34 species, 15.25\%); Number of species which only had one usage was 164 species $(73.54 \%)$, number of species with 2 usages was 59 species $(26.46 \%)$. 
Table 8. List of medicinal plant usages of Tay ethnic minority in Na Hang SUF, Tuyen Quang province

\begin{tabular}{cccc} 
No. & Usage & Frequency & Percentage \\
\hline I & EXTERNAL ADMINISTRATION & 41 & 18.39 \\
1 & Dressing & 34 & 15.25 \\
2 & Bath, shampoo & 7 & 3.14 \\
3 & Holding in mouth & 3 & 1.35 \\
4 & Nose, eye, ear drops & 4 & 1.79 \\
5 & Massage & 16 & 7.17 \\
6 & Apply a thin layer, a spot & 3 & 1.35 \\
7 & Steam bath & & 0.00 \\
II & INTERNAL ADMINISTRATION & 148 & 66.37 \\
8 & Drinking & 5 & 2.24 \\
9 & Eating & 164 & 73.54 \\
III & Number of species with 1 usage & 59 & 26.46
\end{tabular}

\subsection{Use value of medicinal plants}

Medicinal plant resources in Na Hang special-use forests, Tuyen Quang province has been contributing to the work of health care and treatment of communities in the region. There are a lot of herb doctors practicing to treat diseases for people. With experience from the past, they use medicinal plants to treat various diseases effectively. According to the Classification of Diseases by Doctor Vu Quoc Trung
[16], it is divided into 7 groups of diseases, including 53 diseases/symptoms that can be treated with medicinal plants from Tay ethnic minority in $\mathrm{Na}$ Hang special-use forest, Tuyen Quang province. Particularly, 14 diseases to be treated by various medicinal herbs are: Liver tonic, Hepatitis B, Cirrhosis; Cough, asthma; Kidney diseases; Headache; yellow red urine; arthritis; rheumatology; Pimples, rashes; Snakebite; postnatal diseases; tooth decay; sore; health supplement and heat release (Table 9).

Table 9. List of diseases, symptoms which may be treated by medicinal plants in Na Hang special-use forests, Tuyen Quang province (put in order)

\begin{tabular}{|c|c|c|c|}
\hline No. & Name of disease/ symptom & Number of species & Percentage \\
\hline \multirow[t]{2}{*}{$\mathbf{I}$} & INTERNAL DISEASES & & \\
\hline & Diseases caused by climate & & \\
\hline \multirow[t]{2}{*}{1} & - Fever, malaria, flu & 10 & 4.48 \\
\hline & Epidemic diseases & & \\
\hline \multirow[t]{2}{*}{2} & - Diphtheria, pertussis, tetanus & 2 & 0.90 \\
\hline & Heart diseases & & \\
\hline 3 & - Blood pressure & 7 & 3.14 \\
\hline \multirow[t]{2}{*}{4} & - Heart disease & 3 & 1.35 \\
\hline & Hepato-biliary diseases & & \\
\hline \multirow[t]{2}{*}{5} & - Liver tonic, Hepatitis B, Cirrhosis & 22 & 9.87 \\
\hline & Digestive diseases & & \\
\hline 6 & - Vomiting, heartburn & 2 & 0.90 \\
\hline 7 & - Abdominal pain \& Diarrhea & 4 & 1.79 \\
\hline \multirow[t]{2}{*}{8} & - Dysentery & 5 & 2.24 \\
\hline & Respiratory diseases & & \\
\hline \multirow[t]{2}{*}{9} & - Cough, asthma & 12 & 5.38 \\
\hline & Kidney diseases & & \\
\hline \multirow[t]{2}{*}{10} & - Kidney disease & 36 & 16.14 \\
\hline & Neurological diseases & & \\
\hline 11 & - Sedation, insomnia & 3 & 1.35 \\
\hline \multirow[t]{2}{*}{12} & - Neurasthenia & 2 & 0.90 \\
\hline & Diseases of headache, dizziness & & \\
\hline \multirow[t]{2}{*}{13} & - Headache & 13 & 5.83 \\
\hline & Urinary diseases & & \\
\hline 14 & - Diabetes & 3 & 1.35 \\
\hline 15 & - Diuretic & 5 & 2.24 \\
\hline 16 & - Yellow red urine & 17 & 7.62 \\
\hline 17 & - Orchitis & 2 & 0.90 \\
\hline \multirow[t]{2}{*}{18} & - Impotentia coeundi & 2 & 0.90 \\
\hline & Rheumatism diseases & & \\
\hline 19 & - Rheumatism, pain & 12 & 5.38 \\
\hline 20 & - Rheumatology & 11 & 4.93 \\
\hline 21 & - Gout & 2 & 0.90 \\
\hline
\end{tabular}




\begin{tabular}{|c|c|c|c|}
\hline II & $\begin{array}{l}\text { EXTERNAL DISEASES } \\
\text { Pimples, inflammation }\end{array}$ & & \\
\hline 22 & $\begin{array}{l}\text { - Pimples, rashes } \\
\text { Anal disease }\end{array}$ & 31 & 13.90 \\
\hline 23 & $\begin{array}{l}\text { - Hemorrhoids, anal fistula } \\
\text { Diseases caused by worm (parasites) }\end{array}$ & 3 & 1.35 \\
\hline 24 & $\begin{array}{l}\text { - Worm infection } \\
\text { Snakebite, burns, necrosis }\end{array}$ & 2 & 0.90 \\
\hline $\begin{array}{l}25 \\
26\end{array}$ & $\begin{array}{l}\text { - Snakebite } \\
\text { - Burns }\end{array}$ & $\begin{array}{l}8 \\
7\end{array}$ & $\begin{array}{l}3.59 \\
3.14\end{array}$ \\
\hline III & $\begin{array}{l}\text { GYNECOLOGICAL DISEASES } \\
\text { Menstrual diseases }\end{array}$ & & \\
\hline 27 & $\begin{array}{l}\text { - Menstrual disorders } \\
\text { Leucorrhoea }\end{array}$ & 9 & 4.04 \\
\hline 28 & $\begin{array}{l}\text { - Leucorrhoea } \\
\text { Diseases in pregnancy }\end{array}$ & 1 & 0.45 \\
\hline 29 & - Miscarriage & 2 & 0.90 \\
\hline 30 & - Threatened miscarriage & 2 & 0.90 \\
\hline 31 & $\begin{array}{l}\text { - Fetal death } \\
\text { Postpartum diseases }\end{array}$ & 3 & 1.35 \\
\hline $\begin{array}{l}32 \\
33\end{array}$ & $\begin{array}{l}\text { - Postpartum diseases } \\
\text { - Breastfeeding support }\end{array}$ & $\begin{array}{l}9 \\
4\end{array}$ & $\begin{array}{l}4.04 \\
1.79\end{array}$ \\
\hline IV & $\begin{array}{l}\text { PEDIATRIC DISEASES } \\
\text { Diseases in children }\end{array}$ & & \\
\hline $\begin{array}{l}34 \\
35\end{array}$ & $\begin{array}{l}\text { - Mumps } \\
\text { - Sweating }\end{array}$ & $\begin{array}{l}5 \\
4\end{array}$ & $\begin{array}{l}2.24 \\
1.79\end{array}$ \\
\hline $\mathbf{V}$ & $\begin{array}{l}\text { DISEASES OF THE FIVE SENSES } \\
\text { Ear diseases }\end{array}$ & & \\
\hline 36 & $\begin{array}{l}\text { - Inflammation of the parotid } \\
\text { Nose diseases }\end{array}$ & 2 & 0.90 \\
\hline 37 & $\begin{array}{c}\text { - Sinusitis } \\
\text { Dental diseases }\end{array}$ & 3 & 1.35 \\
\hline 38 & $\begin{array}{l}\text { - Cavities } \\
\text { Eye diseases }\end{array}$ & 12 & 5.38 \\
\hline 39 & - Pink eye & 1 & 0.45 \\
\hline VI & $\begin{array}{l}\text { SKIN, VENEREAL DISEASES } \\
\text { Skin diseases }\end{array}$ & & \\
\hline 40 & - Tinea versicolor & 3 & 1.35 \\
\hline 41 & - Jaundice & 1 & 0.45 \\
\hline 42 & - Ulcer disease & 10 & 4.48 \\
\hline 43 & - Scabies & 6 & 2.69 \\
\hline 44 & - Dermatophytosis, Psoriasis & 4 & 1.79 \\
\hline 45 & - Cheek eczema & 2 & 0.90 \\
\hline VII & OTHER GROUPS OF DISEASES & & \\
\hline 46 & - Detoxifying & 4 & 1.79 \\
\hline 47 & - Hemostasis & 6 & 2.69 \\
\hline 48 & - Stomachache & 7 & 3.14 \\
\hline 49 & - Broken limbs, sprains & 4 & 1.79 \\
\hline 50 & - Health supplement & 17 & 7.62 \\
\hline 51 & - heath release & 19 & 8.52 \\
\hline 52 & - Allergy to paint & 2 & 0.90 \\
\hline 53 & - Poliomyelitis & 4 & 1.79 \\
\hline
\end{tabular}

\section{Conclusion}

Na Hang SUF, Tuyen Quang Province has a diverse resource of medicinal plants which are currently known to have 275 species, belonging to 96 families, 204 genera, 4 phyla; of which, the number of medicinal plants that Tay ethnic minority use are 223 species, belonging to 90 families, 179 genera, 4 phyla of vascular plants. Among 223 species, 09 species need to be protected that are listed in the Vietnam Red Data Book, Red List of Medicinal Plants of Vietnam and Decree 32 of the Government.
The medicinal plant resources have been contributing to the work of health care of the community with 53 diseases/symptoms. Tay and Dao ethnic minorities use medicinal plants to treat diseases such as: Liver tonic, Hepatitis B, Cirrhosis; Cough, asthma; Kidney diseases; Headache; yellow red urine; arthritis; rheumatology; Pimples, rashes; Snakebite; postnatal diseases; tooth decay; sore; health supplement and heat release through oral administration (148 species, accounting for $66,37 \%)$, dressing (41 species, $18.39 \%$ ) and bath, shampoo (34 species, 15.25\%). 
Acknowledgement: The findings are funded by the scientific career source of Tuyen Quang province for the provincial-level project: "Investigation, assessment of the status of sources of medicinal plant in some mountainous communes of $\mathrm{Na}$ Hang district, proposal of solutions on preservation and sustainable use of some valuable and potential species", coded DT.21-2013. The authors also thank to the fund from the Institute of Ecology and Biological Resources for the research project coded IEBR.DT.02/1516.

\section{References}

[1] Nguyen Tien Ban (1997) Handbook to reference and identification of the families of angiospermae plants in Vietnam, Agricultural Publishing House, Hanoi.

[2] Ministry of Science and Technology, Vietnamese Academy of Science and Technology (2007) Vietnam Red Data Book (Plants). Publishing House For Science And Technology, Hanoi.

[3] The Government of the S.R. of Vietnam (2006) The Government's Decree no. 32/2006/NĐ-CP in management of endangered, precious and rare forest plants and animals.

[4] Vo Van Chi (2003) Dictionary of Common Plants, Volume I, II. Science and Technology Publishing House, Hanoi.

[5] Vo Van Chi (1997) A dictionary of medicinal plants of Vietnam, Medical Publishing House, Ho Chi Minh city.

[6] Vo Van Chi, Nguyen Duc Minh (2000) Snakes used for medicine and medicine to cure snakebite. Science and Technology Publishing House, Hanoi.

[7] Vo Van Chi (2005) Vegetables and fruits used for food and medicine. Science and Technology Publishing House, Hanoi.

[8] Pham Hoang Ho $(1999,2000)$ An illustrated flora of Vietnam, volume 1-3, Tre Publishing House, Ho Chi Minh city.

[9] Do Tat Loi (1999) Vietnam medicinal plants and herbs. Science and Technology Publishing House, Hanoi.

[10] Tran Dinh Ly (1995) 1900 Useful Plant Species of Vietnam, World Publishing House, Hanoi.

[11] Nguyen Tap (2006) Red List of Medicinal Plants of Vietnam. Journal of Medicinal Materials, 3(11): 97-105.

[12] Nguyen Tap (2006) Handbook of medicinal plants to be protected in Vietnam. Vietnam NTFP Network.

[13] Nguyen Nghia Thin (1999) Manual on research of biodiversity. Agricultural Publishing House, Hanoi.

[14] Nguyen Nghia Thin, Dang Quyet Chien (2006) Biodiversity of plants in $\mathrm{Na}$ Hang Natural Reserve $\mathrm{Na}$ Hang, Tuyen Quang province. Agricultural Publishing House, Hanoi.

[15] National Institute of Medicinal Materials (2006) Medicinal plants and animals used for medicinal purposes in Vietnam, volume I, II. Science and Technology Publishing House, Hanoi.

[16] Vu Quoc Trung (2005) Traditional medicine practice. Science and Technology Publishing House, Hanoi.

[17] Nguyen Thi Hai, Nguyen The Cuong, Tran Huy Thai, Chu Thi Thu Ha, Nguyen Anh Tuan (2015) Medicinal plant resources in the $\mathrm{Na}$ Hang nature reserve, Tuyen Quang province. Proceedings of the 6th National Scientific Conference on Ecology and Biological Resources: 1093-1099. 